\title{
Adaptability to social distancing due to COVID-19 and its moderating effect on stress by gender
}

\author{
Jorge Zamarripa, ${ }^{1}$ Maritza Delgado-Herrada ${ }^{2}$ Raquel Morquecho-Sánchez, ${ }^{1}$ Raúl Baños, ${ }^{3}$ \\ Manuel de la Cruz-Ortega ${ }^{4}$ Héctor Duarte-Félix ${ }^{5}$
}

\footnotetext{
Facultad de Organización Deportiva, Universidad Autónoma de Nuevo León, San Nicolás de los Garza, México.

2 Facultad de Psicología, Universidad Autónoma de Nuevo León, Monterrey, México.

3 Facultad de Deportes, Universidad Autónoma de Baja California, Ensenada, México.

4 Universidad Estatal de Sonora, Unidad Académica Hermosillo, México.

5 Universidad Estatal de Sonora, Unidad Académica Benito Juárez, México.

\section{Correspondence: \\ Jorge Zamarripa \\ Facultad de Organización Deportiva, Universidad Autónoma de Nuevo León. \\ Ciudad Universitaria, s/n, \\ San Nicolás de los Garza, \\ 66455, NL, México. \\ Phone: + 52 (81) 1340-4450 y 51 . \\ Ext. 7634 and Fax: Ext. 7640}

Email: jorge.zamarriparv@uanl.edu.mx
}

Received: 30 June 2020

Accepted: 20 August 2020

Citation:

Zamarripa, J., Delgado-Herrada, M. Morquecho-Sánchez, R., Baños, R. de la Cruz-Ortega, M., \& Duarte-Félix, H. (2020). Adaptability to social distancing due to COVID-19 and its moderating effect on stress by gender. Salud Mental, 43(6), 273-278.

DOI: $10.17711 /$ SM.0185-3325.2020.037

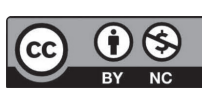

\begin{abstract}
Introduction. The COVID-19 pandemic, originated in China, has affected millions of people worldwide, leading to various situations such as psychological disorders and diseases that affect people's physical and mental health, and disrupt their quality of life. Objective. To analyze stress levels during social distancing due to COVID-19 by gender and to determine the moderating effect of adaptability to the situation. Method. The study is cross-sectional and quantitative, with a descriptive-correlational scope. The sample consisted of 1,173 Mexican subjects (522 males [44.5\%] and 651 females [22.5\%]) with an average age of 25.99 years (DT = 11.19; range $=12-77$ years). Adaptability and perceived stress were measured, obtaining reliability from appropriate instruments. Results. The results indicated that the greater the number of weeks of social distancing, the higher the perceived level of stress. Also, the better people adapt to social distancing, the less stress occurs. Women were observed to have higher levels of stress compared to men. Discussion and conclusion. The findings highlight the importance of adaptability to the stressful situation of the pandemic, because the effect of severe stress on women largely disappears when there is a high level of adaptability to the event.
\end{abstract}

Keywords: Adaptation, stress, COVID-19, adaptability, mental health, Mexico.

\section{RESUMEN}

Introducción. La pandemia del COVID-19, originada en China, ha afectado a millones de personas en todo el mundo y ha provocado diversos problemas como trastornos y enfermedades psicológicas. Todo esto ha afectado la salud física y mental, la calidad de vida de las personas. Objetivo. Analizar los niveles de estrés durante el distanciamiento social debido al COVID-19 en función del género y conocer el efecto moderador de la adaptabilidad a la situación. Método. El estudio es de tipo transversal, cuantitativo y con alcance descriptivo-correlacional. La muestra estuvo conformada por 1,173 sujetos (522 varones [ $44.5 \%$ ] y 651 mujeres [22.5\%]) mexicanos con una media de 25.99 años de edad ( $D T=11.19$; rango $=12-77$ años). Se midió la adaptabilidad y el estrés percibido, y se obtuvieron fiabilidades adecuadas de los instrumentos utilizados. Resultados. Los resultados indicaron que el nivel de estrés percibido es más alto cuanto mayor es la cantidad de semanas en distanciamiento. Asimismo, cuanto mejor se adaptan las personas al distanciamiento social, menos estrés se presenta. Por otra parte, las mujeres fueron las que presentaron niveles más altos de estrés en comparación con los varones. Discusión y conclusión. Los hallazgos destacan la importancia que tiene la adaptabilidad a la situación estresante de la pandemia, debido a que el efecto del estrés marcado en gran medida en las mujeres se pierde cuando el nivel de adaptabilidad ante el acontecimiento es alto.

Palabras clave: Adaptación, estrés, COVID-19, salud mental, México. 


\section{INTRODUCTION}

The coronavirus pandemic, which began in 2019(COVID-19), is a major health crisis affecting several nations. To date, (June 23, 2020), 8,993,659 confirmed cases and 469,587 deaths attributable to this disease have been reported worldwide (World Health Organization [WHO], 2020b). From February 28 to June 23, 2020, there were 180,545 cases and 21,825 confirmed deaths in Mexico (WHO, 2020c).

According to the US Centers for Disease Control and Prevention (CDC), 2020, the outbreak of the disease can be stressful for many people, reducing the quality of life of those who experience it. Stress is the physiological or psychological response to internal or external stressors (VandenBos, 2015), involving changes that affect almost all body systems and influencing how people feel and behave (de Oliveira \& Brito, 2019).

The epidemic requires the implementation of strict social distancing measures to curb the spread of the virus. This situation has also caused stress and uncertainty as it is an unknown and unpleasant experience, since it entails separation from family, friends, and normal daily routines (Onyeaka, Zahid, \& Patel, 2020). Combined with fear of contagion, stigma, and potential information overload, these measures cause chronic stress and are associated with mental health overload (Gao et al., 2020).

Social distancing is a way to prevent people from interacting closely or often enough to spread an infectious disease (Substance Abuse and Mental Health Services Administration [SAMHSA], 2020), and often constitutes a severe stress factor in human beings (Marčinko et al., 2020), which exacerbates personal vulnerabilities, limits options for close and family support (Usher, Bhullar, Durkin, Gyamfi, \& Jackson, 2020) and has caused humans living in volatile family violence situations to be restricted to their homes (Vieira, Garcia, \& Maciel, 2020).

Social distancing can be extremely boring and exhausting, since this response to the pandemic may disrupt people's spare time activities for keeping healthy (such as exercise) and encourage them to engage in activities that may exacerbate the situation (such as drinking more alcohol). Accordingly, efforts to cope with stress during social distancing are extremely important for everyone, posing a series of challenges for individuals and families as they respond to demands and adjust to the situation.

Adaptability to situations refers to the ability of an individual to effectively adjust to changing life circumstances and is characterized by expecting challenges, accepting changes, being flexible, and demonstrating an ability to overcome new difficulties as they arise (Datu, Yuen, \& Chen, 2017). Adaptability is therefore essential to making things work, both in ordinary circumstances and especially in extraordinary circumstances (Wears \& Hettinger, 2013), such as those currently experienced by society.
This study therefore seeks to analyze stress levels during social distancing due to COVID-19 by gender and to determine the moderating effect of adaptability to the situation.

\section{METHOD}

\section{Study design and sample description}

The present study is non-experimental, cross-sectional, and quantitative, with a descriptive-correlational scope. The sample was selected through non-probability convenience sampling, with the following eligibility criteria: 1 . living in Mexico, 2. voluntarily granting or obtaining consent to participate in the study from parents or guardians (in the case of minors), and 3. practicing social distancing at the time of answering the questionnaire. One thousand two hundred and two responses were received, 29 of which were eliminated, 22 because they did not reside in the country and seven because of incomplete or incorrect information in the questionnaires.

The final sample consisted of 1,173 Mexican subjects (522 men [44.5\%] and 651 women [22.5\%]) with a mean age of 25.99 years $(S D=11.19$; range $=12-77$ years $)$. Most participants declared that they were Latinos, students, with completed undergraduate studies and middle socio-economic status (Table 1).

\section{Measurements}

Adaptability to distancing was measured through the items corresponding to the adaptability to the situation sub-scale of the Triarchic Model of Grit Scale (TMGS) developed by Datu et al. (2017). The subscale comprises five items answered on a five-point Likert-type scale ( $1=$ "that's not at all like me"; 5 = "that's a lot like me"). An example of an item is, "I am able to cope with the changing circumstances of life." Previous research (Datu et al., 2017) has reported adequate reliability of this instrument $(\alpha=.85-88)$.

The Perceived Stress Scale (PSS) developed by Cohen, Kamarck, and Mermelstein (1983) was used to measure perceived stress. The scale comprises 14 items (seven with reverse scoring), answered on a five-point Likert-type scale $(0=$ never; $4=$ always $)$. The heading contains the phrase: "During this period of isolation...," and an example of an item 5: "How often have you felt nervous and stressed?" This instrument has shown adequate reliability $(\alpha=.84-86)$ in previous research (Cohen et al., 1983).

\section{Procedure}

Due to the strict social distancing measures, data collection was conducted virtually through a link to the instrument hosted on the QuestionPro ${ }^{\circledR}$ platform through various social 
Tabla 1

Sociodemographic information on study participants

\begin{tabular}{|c|c|c|}
\hline Variable & $f$ & $\%$ \\
\hline \multicolumn{3}{|l|}{ Education } \\
\hline No education & 5 & .4 \\
\hline Elementary school & 2 & .2 \\
\hline Junior high school & 38 & 3.2 \\
\hline Senior high school/Technical & 265 & 22.6 \\
\hline Bachelor's degree & 720 & 61.4 \\
\hline Master's degree /Specialty & 104 & 8.9 \\
\hline Doctorate & 39 & 3.3 \\
\hline \multicolumn{3}{|l|}{ Occupation } \\
\hline Full-time employee & 280 & 23.9 \\
\hline Part-time employee & 102 & 8.7 \\
\hline Unemployed & 35 & 3.0 \\
\hline Self-employed & 69 & 5.9 \\
\hline Housewife & 50 & 4.3 \\
\hline Student & 609 & 51.9 \\
\hline Retiree & 10 & .9 \\
\hline Serviceman or woman & 1 & .1 \\
\hline Other & 17 & 1.4 \\
\hline \multicolumn{3}{|l|}{ Socio-economic status } \\
\hline Low & 40 & 3.4 \\
\hline Lower-middle & 254 & 21.7 \\
\hline Middle & 766 & 65.3 \\
\hline Upper-middle & 108 & 9.2 \\
\hline High & 5 & .4 \\
\hline \multicolumn{3}{|l|}{ Race } \\
\hline Latino & 975 & 83.1 \\
\hline White & 141 & 12 \\
\hline Mulatto & 23 & 2 \\
\hline Black & 13 & 1.1 \\
\hline Indigenous & 15 & 1.3 \\
\hline Asian & 1 & .1 \\
\hline Other & 5 & .4 \\
\hline
\end{tabular}

networks such as Facebook ${ }^{\circledR}$, Twitter ${ }^{\circledR}$, and WhatsApp ${ }^{\circledR}$, during the months of April, May, and June 2020. The purpose of the study was detailed in the description of the instrument, together with instructions for answering. Respondents were asked to answer truthfully, and information was provided on confidentiality and consent for data to be used for research purposes. Only those who gave or obtained the consent of their parents or guardians (in the case of minors) were allowed to read the instrument.

\section{Statistical analyses}

First, descriptive analyses of frequency and central tendency, reliability analyses of the scales using Cronbach's alpha, and Pearson's correlation analysis were conducted to determine the relationship between the study variables. Subsequently, a $t$-test for independent samples and analysis of variance (ANOVA) were performed to determine the differ- ences in means of the study variables by gender and weeks of social distancing. Lastly, a simple moderation analysis (model 1) was performed using the PROCESS V.3.5 macro (Hayes, 2018) in the SPSS Statistics V.21 software package. Confidence intervals ( $95 \%$ ) were generated by bootstrapping 10,000 samples to determine the three effects of the model (effect $b_{1}, b_{2}$ and $b_{3}$ ). Adaptability to the situation was divided into three levels using the pick-a-point approach, resulting in a variable with three groups corresponding to low, intermediate, and high levels of adaptability.

\section{Ethical considerations}

This research was conducted in accordance with international ethical standards, which are consistent with the guidelines of the American Psychological Association (APA) and the Declaration of Helsinki. The study was registered and approved by the ethics review committee of the research coordinating office of the Faculty of Sports Organization of the Universidad Autonoma de Nuevo León (No. REPRIN-FOD-69).

\section{RESULTS}

\section{Reliability, descriptive, and correlation analysis}

The scale of adaptability to the situation $(\alpha=.75)$ and perceived stress $(\alpha=.85)$ had acceptable internal consistency values. However, item 12 (How often have you thought about the things you must accomplish?) was eliminated from the stress scale for having a negative total item correlation $(r=-.06)$.

Descriptive analyses revealed high adaptability $(M=$ 4.23; $S D=.61)$ and moderate stress levels $(M=1.70 ; S D=$ $.62)$ in the study participants. Most subjects reported having spent nine weeks in social distancing (24\%), followed by those who had spent eight $(19.7 \%)$, one $(17.7 \%)$, two $(11.5 \%)$, and five weeks $(10.3 \%)$ doing so. The remaining participants were distributed among those who had spent four $(8.2 \%)$, seven $(5.3 \%)$, six $(2.7 \%)$, ten $(.4 \%)$, and three weeks $(.1 \%)$ in this condition.

The number of weeks spent socially distancing was positively and significantly related to stress $(r=.28, p<.001)$, indicating that stress levels are higher when the number of weeks in isolation is greater. For their part, adaptability and stress were negatively correlated $(r=-.26, p<.001)$, indicating that the better people adapt to social distancing, the less stress they perceive.

\section{Difference between means}

The result of the $t$-test yielded significant differences $\left(t_{(1155)}\right.$ $=-3.01, p=.003, d=-.18 ; 95 \% C I[-.176,-.037])$ in stress 


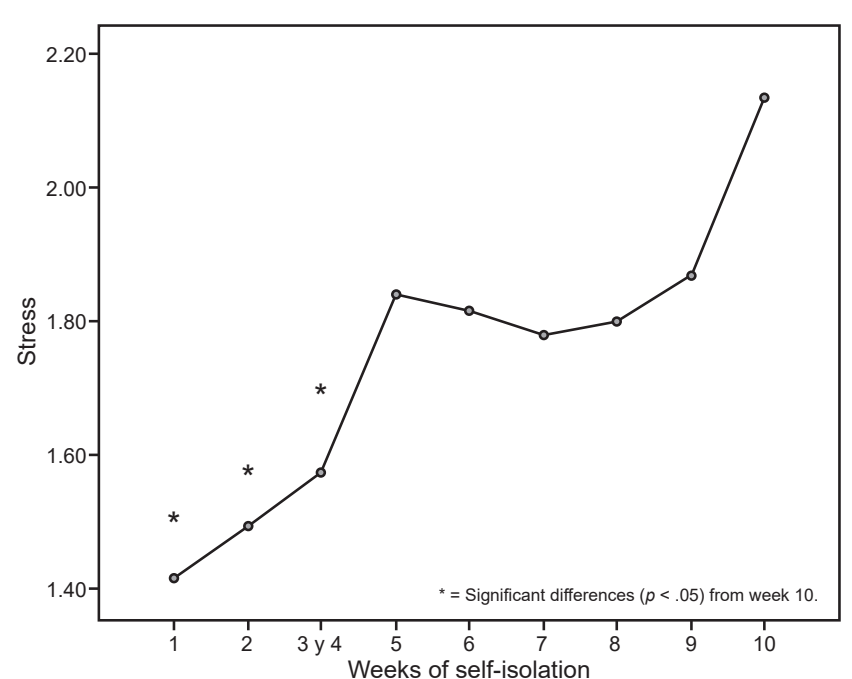

Figure 1. Difference in means between stress levels and length of social distancing.

perception as a function of gender, with women perceiving higher levels $(M=1.75 ; S D=.64)$ than men $(M=1.64$; $S D=.57)$. Conversely, no significant differences were perceived in adaptability to circumstances between the gender groups $\left(t_{(1171)}=.09, p=.923, d=.005 ; 95 \%\right.$ CI [-.068, $.075])$.

For its part, the ANOVA only revealed significant differences between stress perception over weeks $(F=$ $6.996, p<.001, \eta^{2} \mathrm{p}=.05$ ). Because only one person reported having spent three weeks social distancing, they were incorporated into the group that stated it had spent four weeks social distancing, as a result of which the new group was named "three and four weeks." Tukey's post hoc test revealed significant differences in stress perception $(F=$ $13.98, p<.001, \eta_{\mathrm{p}}^{2}=.09$ ) between people who had spent one $(M=1.42 ; S D=.58)$, two $(M=1.49 ; S D=.71)$, three and four weeks $(M=1.57 ; S D=.65)$ and those who had spent ten weeks social distancing $(M=2.14 ; S D=.23)$. This indicates that stress perception is higher in those who have spent two and a half months self-isolating than in those who have done so for a month or less (Figure 1).

\section{Moderation analysis}

The proposed model calculated the moderating effect of adaptability (W) on the interaction between gender (X) and stress $(\mathrm{Y})$. The results revealed that the model was statistically significant $(F[3.1169]=35.060 ; p<.001)$. Regression analyses showed that the effect of adaptability on stress is negative and statistically significant $\left(\mathrm{B}_{\text {[adaptability] }}=-.257, p<.001\right.$ ), indicating that people with greater adaptability perceive less stress, that the effect of the independent variable on the dependent variable is positive and statistically significant $\left(\mathrm{B}_{\text {[gender] }}\right.$ $=.762, p<.001)$, demonstrating that women perceive more

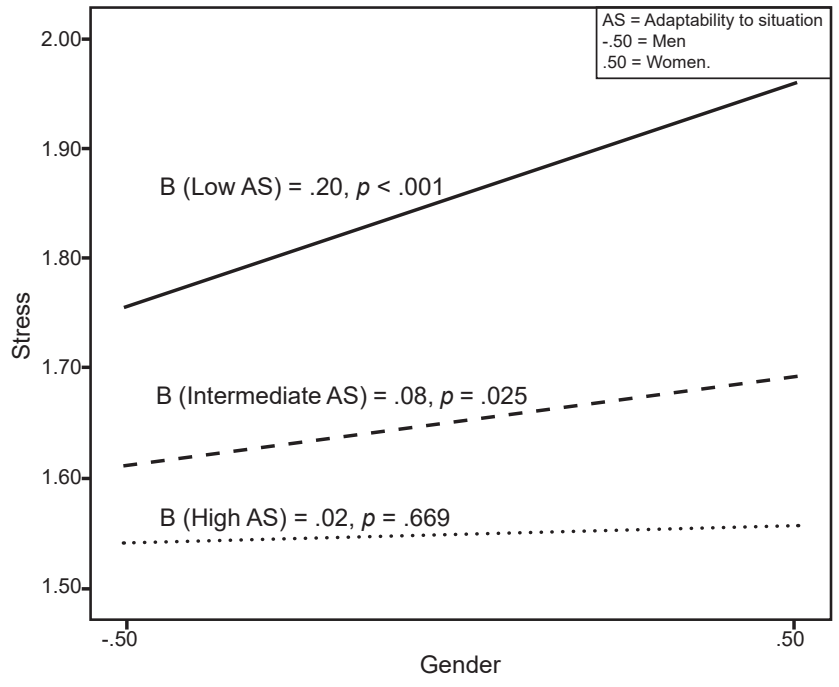

Figure 2. Moderating effect of adaptability to social distancing on stress perception by gender.

stress than men during isolation, and finally, a statistically significant interaction effect of both variables ( $\mathrm{B}_{\text {[genderXadaptability] }}$ $=-.155, p=.005)$ on stress was also found.

Figure 2 shows that in people with low $\left(\vartheta_{\mathrm{X} \rightarrow \mathrm{YM} M}=3.60=\right.$ $.20, p<.001)$ and intermediate $\left(\vartheta_{\mathrm{X} \rightarrow \mathrm{YM}=4.40}=.08, p=.025\right)$ levels of adaptability to the situation, stress levels were greater and significantly higher in women than men. However, this effect disappears in the group of people with high levels of adaptability to the situation since no significant differences were observed between gender groups $\left(\vartheta_{\mathrm{X} \rightarrow \mathrm{Y} / \mathrm{M}=4.80}=.02, p=.669\right)$.

\section{DISCUSSION AND CONCLUSION}

The purpose of this study was to analyze stress levels during social distancing due to COVID-19 by gender and to determine the moderating effect of adaptability to the situation.

The results showed that perceived stress is greater when the number of weeks spent socially distancing is higher. At the same time, the better people adapt to social distancing, the less stress they perceive. Our results are congruent with the findings of Morales (2020), who points out that, due to the length of time of social distancing, human beings have rediscovered themselves as independent beings, capable of adapting to new lifestyles and everyday practices, with the possibility of developing life skills to meet up with others and formulate and adapt social, moral, and ethical rules.

As for gender differences, women reported higher stress levels than men. These findings are consistent with studies conducted by Ishiguro et al. (2019) and Song et al. (2020), where it is argued that men have comparatively lower stress levels than women due to their capacity for psychological recovery. Sex differences in self-reported stress 
are reflected in the perceived lack of psychological support services, which were considered more evident in women than in men. This may be due to poor coping and adaptation to stress, since various studies have found that women are more vulnerable to experiencing psychological distress due to the pandemic (Brooks et al., 2020; Taylor, 2019) and tend to drink more in response to stress (Rodríguez, Litt, \& Stewart, 2020). In addition to the above, there is the possibility that having children at home to care for and educate during the pandemic increases the stress overload in women, since, owing to the prevailing gender roles in Latin America, women take on more substantial care tasks more frequently (Perrin et al., 2015). Previous research supports this since it has been found out that having children at home during the pandemic increases psychological stress (Kisely et al., 2020; Shevlin et al., 2020).

As for the number of weeks of social distancing, the results revealed differences in stress perception between people who have spent one, three- or four-weeks socially distancing compared to those who answered in week ten. This shows that the length of time spent socially distancing is a factor that alters stress levels in people. These findings are consistent with the results of other studies that confirm that longer self-isolation or social distancing produces negative psychological effects such as post-traumatic stress symptoms, anger, and confusion (Bedford et al., 2020; Brooks et al., 2020). These stressors arose because of a longer period of confinement or social distancing, and included the risk of contagion, frustration, boredom, and financial loss.

In conclusion, our findings highlight the importance of adaptability to the pandemic that is currently being experienced worldwide and the stress it entails, since the effect of the latter, which is more pronounced in the group of women, disappears when there is a high level of adaptability to the situation.

The practical implications of this study focus on how to act to adapt to social distancing during COVID-19 and adopt wellness strategies for mental health. In the first instance, it is essential to maintain a positive attitude by avoiding information overload, taking care of one's body through the intake of healthy, well-balanced foods, establishing and following a routine of daily activities that includes regular exercise (at least 30 minutes a day of moderate to vigorous activity, five times a week), and other hobbies or activities that are enjoyed and serve to relax, get enough sleep (at least seven hours), and maintain contact by phone or online with friends and family (European Psychiatric Association [EPA], 2020; National Suicide Prevention Lifeline [NSPL], 2020; Secretaría de Salud [SS], 2020; SAMHSA, 2020; WHO, 2020a).

Limitations in this study include the fact that it is cross-sectional, with a population drawn only from Mexico and due to the constraints of social distancing, data were collected through various virtual media. For future studies, the inclusion of different variables that could enhance or provide a broader overview of the conclusions of the present study is suggested, such as the use of harmful substances (such as alcohol, tobacco, and/or drugs), sleep quality and having children at home.

\section{Funding}

None.

\section{Conflict of interest}

The authors declare they have no conflicts of interest.

\section{REFERENCES}

Bedford, J., Enria, D., Giesecke, J., Heymann, D. L., Ihekweazu, C., Kobinger, G., ... Wieler, L. H. (2020). COVID-19: towards controlling of a pandemic. The Lancet, 395(10229), 1015-1018. doi: 10.1016/S0140-6736(20)30673-5

Brooks, S. K., Webster, R. K., Smith, L. E., Woodland, L., Wessely, S., Greenberg, N., \& Rubin, G. J. (2020). The psychological impact of quarantine and how to reduce it: rapid review of the evidence. Lancet, 395(10227), 912-920. doi: 10.1016/S0140-6736(20)30460-8

Centers for Disease Control and Prevention [CDC]. (2020). Coronavirus Disease 2019 (COVID-19). Daily Life \& Coping. Stress and Coping. Atlanta, GA, USA: U.S. Department of Health \& Human Services. Retrieved from https://www.cdc.gov/ coronavirus/2019-ncov/daily-life-coping/managing-stress-anxiety.html

Cohen, S., Kamarck, T., \& Mermelstein, R. (1983). A global measure of perceived stress. Journal of Health and Social Behavior, 24(4), 385-396. doi: $10.2307 / 2136404$

Datu, J. A. D., Yuen, M., \& Chen, G. (2017). Development and validation of the Triarchic Model of Grit Scale (TMGS): Evidence from Filipino undergraduate students. Personality and Individual Differences, 114, 198-205. doi: 10.1016/j. paid.2017.04.012

European Psychiatric Association [EPA]. (2020). COVID-19 Resource Centre - EPA Recommendations. Retrieved from https://www.europsy.net/covid-19-resourcecentre/

Gao, J., Zheng, P., Jia, Y., Chen, H., Mao, Y., Chen, S., ... Dai, J. (2020). Mental health problems and social media exposure during COVID-19 outbreak. PLoS One, 15(4), e0231924. doi: 10.1371/journal.pone.0231924

Hayes, A. F. (2018). Introduction to mediation, moderation, and conditional process analysis. A regression-based approach, (2nd ed.). New York, NY: The Guilford Press.

Ishiguro, A., Inoue, M., Fisher, J., Inoue, M., Matsumoto, S., \& Yamaoka, K. (2019). Gender-Based Risk and Protective Factors for Psychological Distress in the Midterm Recovery Period Following the Great East Japan Earthquake. Disaster Medicine and Public Health Preparedness, 13(3), 487-496. doi: 10.1017/dmp.2018.80

Kisely, S., Warren, N., McMahon, L., Dalais, C., Henry, I., \& Siskind, D. (2020). Occurrence, prevention, and management of the psychological effects of emerging virus outbreaks on healthcare workers: rapid review and metaanalysis. BMJ, 369, m1642. doi: 10.1136/bmj.m1642

Marčinko, D., Jakovljević, M., Jakšić, N., Bjedov, S., \& Mindoljević Drakulić, A. (2020). The Importance of Psychodynamic Approach during COVID-19 Pandemic. Psychiatria Danubina, 32(1), 15-21. doi: 10.24869/psyd.2020.15

Morales, J. (2020). Oportunidad o crisis educativa: reflexiones desde la psicología para enfrentar los procesos de enseñanza-aprendizaje en tiempos de Covid-19. Revista Internacional de Educación para la Justicia Social, 9(3). Retrieved from https://revistas.uam.es/riejs/article/view/12228

National Suicide Prevention Lifeline [NSPL]. (2020). Emotional Wellbeing During the COVID-19 Outbreak. Retrieved from https://suicidepreventionlifeline.org/currentevents/supporting-your-emotional-well-being-during-the-covid-19-outbreak/

de Oliveira, G. M., \& Brito, C. F. (2019). Influence of social isolation and aggressive behavior in the appearance of Depression-like in Experimental model. Archives of Depression and Anxiety, 5(2), 56-64. doi: 10.17352/2455-5460.000040 
Onyeaka, H. K., Zahid, S., \& Patel, R. S. (2020). The Unaddressed Behavioral Health Aspect During the Coronavirus Pandemic. Cureus, 12(3), e7351. doi: 10.7759/ cureus. 7351

Perrin, P. B., Panyavin, I., Paredes, A. M., Aguayo, A., Macias, M. A., Rabago, B., ... Arango-Lasprilla, J. C. (2015). A disproportionate burden of care: Gender differences in mental health, health-related quality of life, and social support in Mexican multiple sclerosis caregivers. Behavioural Neurology, 2015, 283958. doi: $10.1155 / 2015 / 283958$

Rodriguez, L. M., Litt, D. M., \& Stewart, S. H. (2020). Drinking to cope with the pandemic: The unique associations of COVID-19-related perceived threat and psychological distress to drinking behaviors in American men and women. Addictive Behaviors, 110, 106532. doi: 10.1016/j.addbeh.2020.106532

Secretaría de Salud [SS]. (2020). Recomendaciones para cuidar la salud mental de adultos mayores durante la pandemia COVID-19. Retrieved from https://coronavirus.gob.mx/wp-content/uploads/2020/06/SaludMental_ AdultosMayores.pdf

Shevlin, M., McBride, O., Murphy, J., Gibson Miller, J., Hartman, T. K., Levita, L., ... Bentall, R. (2020). Anxiety, Depression, Traumatic Stress, and COVID-19 Related Anxiety in the UK General Population During the COVID-19 Pandemic. UK Population Mental Health and COVID-19. doi:10.31234/osf.io/hb6nq

Song, K., Xu, R., Stratton, T., Kavcic, V., Luo, D., Hou, F., ... Jiang, Y. (2020). Sex differences and Psychological Stress: Responses to the COVID-19 epidemic in China. MedRxiv. doi: 10.1101/2020.04.29.20084061

Substance Abuse and Mental Health Services Administration [SAMHSA]. (2020). Taking Care of Your Behavioral Health: Tips for Social Distancing, Quarantine,
And Isolation During An Infectious Disease Outbreak. Retrieved from https:// store.samhsa.gov/sites/default/files/SAMHSA_Digital_Download/PEP20-0101-007_2.pdf

Taylor, S. (2019). The Psychology of Pandemics: Preparing for the next global outbreak of infectious disease. Cambridge: Scholars Publishing.

Usher, K., Bhullar, N., Durkin, J., Gyamfi, N., \& Jackson, D. (2020). Family violence and COVID-19: Increased vulnerability and reduced options for support. International Journal of Mental Health Nursing, 29(4), 549-552. doi: 10.1111/ inm. 12735

VandenBos, G. R. (Ed.). (2015). APA dictionary of psychology, (2nd ed.). American Psychological Association. doi: 10.1037/14646-000

Vieira, P. R., Garcia, L. P., \& Maciel, E. (2020). Isolamento social e o aumento da violência doméstica: o que isso nos revela? Revista Brasileira de Epidemiologia, 23, e200033. doi: 10.1590/1980-549720200033

Wears, R. L., \& Hettinger, A. Z. (2013). The tragedy of adaptability. Annals of Emergency Medicine, 63(3), 338-339. doi: 10.1016/j.annemergmed.2013.10.035

World Health Organization [WHO]. (2020a). Mental health and psychosocial considerations during the COVID-19 outbreak. Retrieved from https://www. who.int/publications/i/item/WHO-2019-nCoV-MentalHealth-2020.1

World Health Organization [WHO]. (2020b). WHO Coronavirus Disease (COVID-19) Dashboard. Retrieved from https://covid19.who.int

World Health Organization [WHO]. (2020c). WHO Coronavirus Disease (COVID-19) Dashboard. México. Retrieved from https://covid19.who.int/ region/amro/country/mx 